\title{
Front Matter: Volume 9316
}

, "Front Matter: Volume 9316," Proc. SPIE 9316, Multimodal Biomedical Imaging X, 931601 (9 April 2015); doi: 10.1117/12.2192259

SPIE. Event: SPIE BiOS, 2015, San Francisco, California, United States 


\section{PROGRESS IN BIOMEDICAL OPTICS AND IMAGING}

\section{Multimodal Biomedical Imaging $X$}

Fred S. Azar

Xavier Intes

Editors

7 February 2015

San Francisco, California, United States

Sponsored and Published by

SPIE

Volume 9316 
The papers included in this volume were part of the technical conference cited on the cover and title page. Papers were selected and subject to review by the editors and conference program committee. Some conference presentations may not be available for publication. The papers published in these proceedings reflect the work and thoughts of the authors and are published herein as submitted. The publisher is not responsible for the validity of the information or for any outcomes resulting from reliance thereon.

Please use the following format to cite material from this book:

Author(s), "Title of Paper," in Multimodal Biomedical Imaging X, edited by Fred S. Azar, Xavier Intes, Proceedings of SPIE Vol. 9316 (SPIE, Bellingham, WA, 2015) Article CID Number.

ISSN: 1605-7422

ISBN: 9781628414066

Published by

SPIE

P.O. Box 10, Bellingham, Washington 98227-0010 USA

Telephone +1 3606763290 (Pacific Time) · Fax +1 3606471445

SPIE.org

Copyright $@ 2015$, Society of Photo-Optical Instrumentation Engineers.

Copying of material in this book for internal or personal use, or for the internal or personal use of specific clients, beyond the fair use provisions granted by the U.S. Copyright Law is authorized by SPIE subject to payment of copying fees. The Transactional Reporting Service base fee for this volume is $\$ 18.00$ per article (or portion thereof), which should be paid directly to the Copyright Clearance Center (CCC), 222 Rosewood Drive, Danvers, MA 01923. Payment may also be made electronically through $\mathrm{CCC}$ Online at copyright.com. Other copying for republication, resale, advertising or promotion, or any form of systematic or multiple reproduction of any material in this book is prohibited except with permission in writing from the publisher. The CCC fee code is $1605-7422 / 15 / \$ 18.00$.

Printed in the United States of America.

Publication of record for individual papers is online in the SPIE Digital Library.

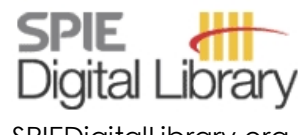

SPIEDigitalLibrary.org

Paper Numbering: Proceedings of SPIE follow an e-First publication model, with papers published first online and then in print. Papers are published as they are submitted and meet publication criteria. A unique citation identifier (CID) number is assigned to each article at the time of the first publication. Utilization of CIDs allows articles to be fully citable as soon as they are published online, and connects the same identifier to all online, print, and electronic versions of the publication. SPIE uses a six-digit CID article numbering system in which:

- The first four digits correspond to the SPIE volume number.

- The last two digits indicate publication order within the volume using a Base 36 numbering

system employing both numerals and letters. These two-number sets start with 00, 01, 02, 03, 04, $05,06,07,08,09,0 A, 0 B \ldots$. 0Z, followed by 10-1Z, 20-2Z, etc.

The CID Number appears on each page of the manuscript. The complete citation is used on the first page, and an abbreviated version on subsequent pages. 


\title{
Contents
}

\author{
$\checkmark$ Authors \\ vii Conference Committee
}

IMAGE PROCESSING TECHNIQUES

931602 Mammogram incorporated DOI with transmission and reflection parallel scanning [9316-1]

931603 Dense motion analysis and segmentation of ultrasound images [9316-2]

931604 Tomographic fluorescence reconstruction by a spectral projected gradient pursuit method [9316-3]

931605 Systematic optimization of MRI guided near infrared diffuse optical spectroscopy in breast [9316-4]

\section{CLINICAL APPLICATIONS}

931607 Illumination-compensated non-contact imaging photoplethysmography via dual-mode temporally coded illumination [9316-6]

931608 Multi-modal contrast of tissue anatomy enables correlative biomarker imaging [9316-7]

$93160 \mathrm{~A} \quad$ High-resolution motion-compensated imaging photoplethysmography for remote heart rate monitoring [9316-9]

9316 0C Dual multispectral and 3D structured light laparoscope [9316-11]

PRECLINICAL / HYBRID IMAGING

93160 Development of a multi-scale and multi-modality imaging system to characterize tumors and their microenvironment in vivo [9316-18]

$93160 \mathrm{~J} \mathrm{Co-registration} \mathrm{of} \mathrm{ultrasound} \mathrm{and} \mathrm{frequency-domain} \mathrm{photoacoustic} \mathrm{radar} \mathrm{images} \mathrm{and}$ image improvement for fumor detection [9316-19]

9316 OK Multi-modality imaging using a handheld gamma camera and MRI for tumor localization [9316-20]

$93160 \mathrm{M} \quad$ Microscopic x-ray luminescence computed tomography [9316-22] 
POSTER SESSION

9316 ON Non-contact assessment of melanin distribution via multispectral temporal illumination coding [9316-23]

931600 Acquisition of priori tissue optical structure based on non-rigid image registration [9316-24]

9316 OP Photoacoustic tomography guided diffuse optical tomography for small-animal model [9316-25]

9316 OR Correlative super-resolution fluorescence microscopy combined with optical coherence microscopy [9316-12] 


\section{Authors}

Numbers in the index correspond to the last two digits of the six-digit citation identifier (CID) article numbering system used in Proceedings of SPIE. The first four digits reflect the volume number. Base 36 numbering is employed for the last two digits and indicates the order of articles within the volume. Numbers start with 00, 01, 02, 03, 04, 05, 06, 07, 08, 09, 0A, 0B...0Z, followed by 10-1Z, 20-2Z, etc.

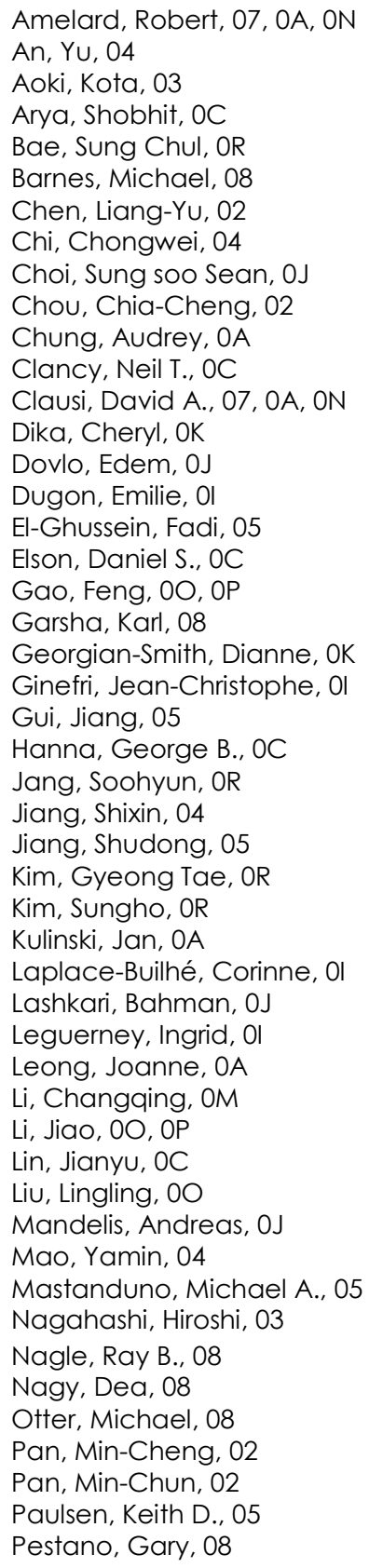

Pogue, Brian W., 05

Polrot, Mélanie, 01

Roberts, Esteban, 08

Robin, Sandra, 0 l

Rouffiac, Valérie, 0 l

Salomé-Desnoulez, Sophie, ol

Scharfenberger, Christian, 07, 0A, ON

Sebrié, Catherine, 01

Ser-Leroux, Karine, 0

Shim, Sang-Hee, OR

Sun, Shen-Yi, 02

Tian, Jie, 04

Ventura, Franklin, 08

Wan, Wenbo, 0O, OP

Wang, Xiao Yu, OA

Wang, Yihan, 0O, OP

Wong, Alexander, 07, OA, ON

$\mathrm{Xu}$, Junqing, 05

Yang, Xin, 04

Ye, Jinzuo, 04

Yokoyama, Ryo, 03

Yu, Jhao-Ming, 02

Zhang, Kun, OM

Zhang, Wei, OM

Zhang, Yan, OO, OP

Zhao, Yan, 05

Zhu, Dianwen, OM 
Proc. of SPIE Vol. $9316931601-6$

Downloaded From: https://www.spiedigitallibrary.org/conference-proceedings-of-spie on 26 Apr 2023 Terms of Use: https://www.spiedigitallibrary.org/terms-of-use 


\title{
Conference Committee
}

\author{
Symposium Chairs
}

James G. Fujimoto, Massachusetts Institute of Technology

(United States)

R. Rox Anderson, Wellman Center for Photomedicine,

Massachusetts General Hospital (United States) and Harvard

School of Medicine (United States)

Program Track Chairs

Tuan Vo-Dinh, Fitzpatrick Institute for Photonics, Duke University (United States)

Anita Mahadevan-Jansen, Vanderbilt University (United States)

Conference Chairs

Fred S. Azar, Philips Medical Systems (United States)

Xavier Intes, Rensselaer Polytechnic Institute (United States)

Conference Program Committee

Caroline Boudoux, Ecole Polytechnique de Montréal (Canada)

Christophe Chefd'hotel, Ventana Medical Systems, Inc.

(United States)

Yu Chen, University of Maryland, College Park (United States)

Qianqian Fang, Massachusetts General Hospital (United States)

Sergio Fantini, Tufts University (United States)

Gultekin Gulsen, University of California, Irvine (United States)

Theodore J. Huppert, University of Pittsburgh (United States)

Tim Nielsen, Philips Research (Germany)

Vasilis Ntziachristos, Helmholtz Zentrum München GmbH (Germany)

Brian W. Pogue, Thayer School of Engineering at Dartmouth

(United States)

Siavash Yazdanfar, GE Global Research (United States)

Arjun G. Yodh, University of Pennsylvania (United States)

Session Chairs

1 Image Processing Techniques

Fred S. Azar, Philips Medical Systems (United States)

2 Clinical Applications

Hamid Dehghani, The University of Birmingham (United Kingdom) 
3 Multimodality Microscopy

Fred S. Azar, Philips Medical Systems (United States)

4 Preclinical / Hybrid Imaging

Caroline Boudoux, Ecole Polytechnique de Montréal (Canada) 